\title{
Child Friendly Village Program as an Effort to Prevent Crimes of Violence against Children in Temusai Village, Siak Regency
}

\author{
Elmayanti ${ }^{1}$, Evi Deliana $\mathrm{HZ}^{1^{*}}$, Mukhlis $\mathrm{R}^{1}$ \\ ${ }^{1}$ Faculty of Law, Universitas Riau, Indonesia \\ *Correspondence: deliana.unri@gmail.com
}

\section{ARTICLE HISTORY \\ Received: 27.07.2021 \\ Accepted: 26.12.2021 \\ Published: 27.12.2021}

\section{ARTICLE LICENCE}

Copyright @ 2021 The Author(s): This is an

open-access article distributed under the terms of the Creative Commons Attribution

ShareAlike 4.0 International (CC BY-SA 4.0)

\begin{abstract}
Kampung Temusai has been designated as a village worthy of childrendesignated by the Bungaraya District. The formulation of the problem in this study is, what are the forms of childfriendly village programs as an effort to prevent child abuse in Temusai village and what are the factors that become obstacles in the implementation of the child-friendly village program and what are the efforts done in coming these obstacles. This research was conducted in Temusai Village. This type of research is sociological juridical with an emphasis on field research. The sociological juridical approach is carried out because the problems studied revolve around how the law applies in society. Judging from its nature, this research is descriptive, because it intends to describe the reality clearly and systematically. The Child Friendly Village Program that has been carried out in Temusai Village is the Community-Based Integrated Child Protection Campaign (PATBM), Maghrib study Program, Collaboration and coordination with various parties in supporting the Child Friendly District Program (KRA). The factors that become obstacles in implementing the child-friendly village program in Temusai village are Lack of Professional Human Resources, Limited technical guidance, Limited budget in running existing programs, Lack of supporting facilities and infrastructure for the Child Friendly Village Program and Lack of awareness community in supporting the Child Friendly Village program. Efforts made to overcome obstacles in the implementation is Coordinating with the local government regarding the budget which is still very minimal.

Keywords: Village Worthy of Children; Child Abuse; Program
\end{abstract}

\section{Introduction}

Children are the next generation of the nation and the successors of the existing development struggle. Children are a mandate as well as a gift from God Almighty, which we must always protect because they have inherent dignity, worth and rights as human beings that must be upheld. Children's rights are part of the human rights contained in the 1945 Constitution and the United Nations Convention on the rights of children.

In terms of national and state life, children are buds, potentials, the future of the nation and the next generation of the ideals of the nation's struggle, have a strategic role and have special characteristics and characteristics that ensure the continuity of the existence of the nation and state in the future. Therefore, so that every child will be able to take on these responsibilities, children need to have the widestopportunity to grow and develop optimally, both physically, mentally and socially and with noble character. provide guarantees for the fulfillment of their rights and treatment without discrimination (Perdana, 2019).

Protection of children is not limited to the government, but also by parents, families and the community to be responsible for maintaining and maintaining the human rights of the child. In this case, the government is responsible for providing facilities for children, especially to ensure optimal growth and development. In addition, Article $28 \mathrm{~B}$ of the 1945 Constitution states that the state guarantees thatevery child has the right to survival, growth and developmentand the right to protection from violence and discrimination.

Children are often victims of violence, be it at school, where they play, even within their own family environment, which should be their place of refuge (Andini, Sulistyowati, \& Al., 2019). Violence experienced by children varies, there is physical and psychological violence. Both physical and psychological violence, this violence has a very bad impact on children's development, especially their psychological development. Children's 
delinquency is the most frequent cause of parental anger, so that children receive punishment and when accompanied by emotions, parents do nothesitate to hit or do physical violence, and it is not uncommon for parents to say rude words to their children (Rusmiyati \& Hikmawati, 2018).

The problem of crime with the mode of violence then becomes a serious problem faced by almost every nation and country on this earth. Various discussions, seminars and scientific meetings are held to find solutions that are considered appropriate regarding the crimes that are happening and are troubling the community. In the daily social sphere, the problem of violence is associated with criminal cases which tend to be increasingly violent and brutal (Nuswantara \& Savitri, 2018).

Crimes with the mode of violence seem to have ups and downs in society. The problem of crime remains a frightening specter for society, whose emergence is often unpredictable or suddenly occurs in an environmentand community that was previously never predicted to give birth to a crime categorized as aggravating.

In a community building previously known to have noble teachings, which popularize the principles of civilized life and social relations that uphold moral and religious values, in reality this is not always the case. This means that people who have the teachings of a noble civilization are quite prone to various modes of crime. Not a few social, political, economic, religious and legal actors are trapped in the denial of noble values (Wahid \& Irfan, 2001).

Every human being, has inherent justice values and is the result of his spiritual or soul processing. For judges as law enforcers, spiritual justice is realized through law which functions as a tool, as a method and output in a legal dispute (Salam \& Suhartono, 2020). Radbruch states that justice should be considered as one of the components of the idea of law. Law and justice as two sides of a coin, if justice is described as material and law as a form, then the value of justice is material that must fill the form of law. While the law is a form that must protect the value of justice, thus justice has a normative and constitutive nature for law. Justice is normative for law because it functions as a transcendental prerequisite that underlies every dignified law. Justice is the moral foundation of law and at the same time the benchmarkfor a positive legal system. In other words, justice is always the base of the law. Withoutjustice, a rule does not deserve to be called a law.

Protection of child victims of crime as regulated in Law Number 35 of 2014 concerning Amendments to Law Number 23 of 2002 concerning Child Protection. In Article 1 paragraph (2) Child Protection is all activities that guarantee and protect children and their rights so that they can live, grow and develop and participate optimally in accordance with human dignity and protection from violence and discrimination. Protection of children is the obligation and responsibility of all of us, child victims must get attention and protection of their rights.

Handling cases of children who are in conflict with the law, especially child victims, must be handled specifically both repressively and preventively in order to create a good and prosperous future for children. In Law Number 11 of 2012 concerning the Juvenile Criminal Justice System, there are three parts to children who are in a case with the law, this can be seen in the provisions of Article 1 paragraph (4) of Law Number 11 of 2012 concerning the Juvenile Criminal Justice System which states that: "Children who are victims of criminal acts, hereinafter referred to as child victims, are children under the age of 18 (eighteen) years who experience physical, mental and/or economic losses caused by criminal acts.

Table 1. Cases of violence against children

\begin{tabular}{cccc}
\hline No & Year & $\begin{array}{c}\text { Number of cases of } \\
\text { violence againstchildren }\end{array}$ & Case handling \\
\hline 1 & 2017 & 33 cases & $\begin{array}{c}\text { Counseling by a Psychologist, Investigation report, } \\
\text { implementation of diversion }\end{array}$ \\
\hline 2 & 2018 & 25 cases & $\begin{array}{c}\text { Counseling by a Psychologist, Investigation report, } \\
\text { implementation of diversion }\end{array}$ \\
\hline 3 & 2019 & 68 cases & $\begin{array}{c}\text { Psychological examination by a psychologist, } \\
\text { mentoring and counseling, investigation, diversion }\end{array}$ \\
\hline
\end{tabular}




\section{Source:P2TP2A Annual Report Siak Regency}

The most common forms of violence against children in Siak Regency are sexual violence and physical violence. The causes of sexual violence against children include the negligence of parents who do not pay attention to the growth and development and association of children, the low morality and mentality of the perpetrators so that they cannot control their passions or behavior and economic factors that make the perpetrators easily smooth out their plans by giving promises to the victims. . Sexual violence againstchildren is an example of a violation of human rights, especially the rights of children. The fact that there are many cases of sexual abuse that afflicts children indicates that they tend to receive less attention, protection, and are often neglected (H. Salim, 2010).

Children who violate the law or commit criminal acts are strongly influenced by several other factors outside of the child such as association, education, playmatesand so on, because criminal acts committed by children in general are a process of imitating or being influenced by negative actions from adults or other people. The impact of the treatment of violence on children actually causes trauma and leaves growth and developmentabnormalities that will affect their adulthood later. The types of crimes that are most often committed by children in Siak Regency are theft and immorality. The trend of increasing child criminal behavior cannotbe separated from the currentopen flow of information. It is so easy for the mass media to broadcast criminal acts, even detailing how these crimes were committed. In addition, the need for consumerism and hedonism also causes children to take instant ways to fulfill their desires.

Furthermore, in Law Number 11 of 2012 concerning the Juvenile Criminal Justice System, Article 90 paragraph (1) explains that Child victims and Child witnesses are entitled to "medical rehabilitation and social rehabilitation efforts, both within the institution and outside the institution". Medical rehabilitation is a process of integrated treatment activities by restoring the physical condition of the child, child victim and or child witness. Then what is meant by social rehabilitation is the process of integrated recovery activities, both physically, mentally and socially, so that the victim's child, and or the witness's child can return to carrying out social functions in life in society.

Protection of children in conflict with the law is an effort to protect children and their rights so that they can grow and develop optimally without violence and discrimination. is increasing, of course, very concerning where the perpetrators are not only adults but also children (Wijaya \& Anantaa, 2016).

Siak Regency, which represents Riau Province, received an award as a Child-friendly Regency with a Primary predicate in 2013. Then two years later, in 2015, Siak Regency still received the same award with the same predicate. In 2017 the assessment of Child-friendly District, Siak Regency still received the same award but here there was an increase, from primary to intermediate. This is the result of hard work from all parties and ranks of the Siak Regency Governmentand related elements.

The protection and handling of women and children victims of violence in Siak Regency is realized through Siak Regency Regional Regulation No. 09 of 2016 concerning Women's Empowerment and Protection, Siak Regency's Regional Regulation No. 09 of 2015 concerning the Implementation of Child Protection and Siak Regent Regulation No. 39 of 2017 concerning Service Centers. Integrated Women and Children Empowerment(P2TP2A) as a service provider for women and children in an effort to fulfill information and needs in the fields of skills, health, economics, politics and law, protection and prevention of violence and trafficking in women and children.

Temusai Village has also been designated as a Child Friendly Village designated by the Bungaraya District The appointment is based on the assessment that so far in the village there has never been violence against children, whether physical, sexual and so on. In addition, the village government programs to become a Childfriendly Village have been made, both the child-friendly organizational structure and all the needs to become a child-friendly village have been formed.

One of the village programs that has been carried out is the Community-Based Integrated Child Protection Campaign (PATBM) in Siak Regency in this village, so it is hoped that with this campaign the community can understand and care more about children and apply it in everyday life. The village of Temusai has already formed child-friendly managementa few months or years ago. From the village first formed, then the district and district. If the village is notformed, of course the district will not get the nickname child-friendly district/city. These villages will develop their own country to be child-friendly, child-friendly and self-supporting, and at the very least, the community has thoughts and understandings that represent the developmental needs of children. 
Temusai Village is a newly formed village based on Regional Regulation No. 5 of 2009 concerning the Formation of Temusai, Dayang Suri and Suak Merambai Villages in Bungaraya District, in order to increase the capabilities and potentials possessed and to administer village government efficiently and improve services and welfare of the village community. temusai. Therefore, it is still necessary to improve and do many things for the development of becoming a better child-friendly village and a child-friendly village, so it is hoped that the participation and participation of the community to improve and realize better child-friendly village programs in the future.

\section{Methodology}

The field research was carried out in Temusai Village, Bunga Raya District, Siak Regency. Temusai Village was chosen as the only village in Bunga Raya District as a child-friendly village, which has also established childfriendly programs and cares about the development and protection of children from all forms of violence against children, so that it is expected to be able to overcome and prevent occurrence of violence against children.

Sampling from the population was carried out in this study using the purposive sampling method (determining the party to be sampled was a certain party deemed to be in accordance with the criteria studied). From the existing population, several samples were taken to be used as respondents in providing data to researchers. The population referred to in this study are the parties related to the research theme.

The type of research used in this research is sociological legal research, namely research conducted by identifying the law and how the effectiveness of the implementation of the law applies in the community or reviewing the state of the problems that exist in the field associated with applicable legal aspects and those manage the problem. This research is a study that focuses on individual or community behavior in relation to the law. Judging from its nature, this research is a descriptive analysis, which describes an eventfrom the point of view of a particular law in society or describes a matter in a certain area, especially with regard to the title of this research, because it intends to describe the reality that is being studied clearly and systematically. . Data collection techniques through document studies and interviews. All data and materials obtained from research materials are compiled and analyzed qualitatively, namely research procedures that produce descriptive data, namely what is stated in writing or verbally and real behavior, researched and studied as a whole to find out and reveal symptoms. Symptoms that arise and are investigated

\section{Result and Discussion}

\subsection{Forms of Child Friendly Village Programs as an Effort to Prevent Crimes of Violence against Children in Temusai Village, Bunga Raya District, Siak Regency}

The struggle to prepare children as a quality generation means building and prospering children's lives as early as possible, starting from the time the child is in the womb, then being born and being in family care, until the child grows up and enters a larger environment, namely the community. In the process of growth and development, children also have needs that mustbe met in order to grow and develop optimally. These needs are not only related to physical needs, but also social and psychological needs, as well as an environment that supports the development of all their potential. A good environment will produce good children who will later develop into adults and are in a wider environment, namely the region and the country and the world.

Children are the development capital and the key to the nation's progress in the future. As a form of efforts to fulfill children's rights, the governmentmust immediately realize a Child Friendly City (KLA). Child Friendly City is a districtcity development system that integrates government, community and business commitments and resources that are planned in a comprehensive and sustainable manner in policies, programs and activities to fulfill children's rights. The interests and protection of children are one of the considerations in building child -friendly city facilities, because children have special needs. The Government through the Ministry of Women's Empowerment and Child Protection of the Republic of Indonesia,

The KLA policy aims to synergize the resources of the government, the community, and the business world so that the fulfillment of the rights of Indonesian children can be more ensured. This policy is an implementation of a follow-up to the global commitment through "World Fitfor Children", which the Government of Indonesia has also adopted. Indonesia is a member of the United Nations that has committed internationally to support the world movement in creating a World Fit for Children. This commitment has been realized since the signing of the 
Ratification of the Convention on the Rights of the Child (CRC) through Presidential Decree No. 36/1990, Natio nal Program for Indonesian Children in 2015, Law No. 23/2002 on Child Protection.

Child-friendly Regency/City (KLA) indicators since 2017 have changed from 31 indicators to 24 indicators based on the substance of children's rights which are grouped into 5 (five) clusters of fulfilling children's rights in the Convention on the Rights of the Child (KHA), that is:

a) Civil rights and freedoms

b) Family environmentand alternative care

c) Basic health and well-being

d) Education, use of leisure time and cultural arts activities, as well as

e) Special protection.

Child Friendly City as a step to create an environment that can aspire to children's rights through local government goals, activities, programs and policies where if the governmentcan fulfill and aspire to all children's rights then this will create conducive conditions for children to grow and develop. develop well and the environment where the child lives will also provide protection for the child. Children can grow and develop properly, their rights are fulfilled and protected as well as to ensure that the State is really present in the development of Indonesian women and children.

The strategy for developing child-friendly districts/cities is mainstreaming children's rights and integrating children's rights into every process of preparation (policies, programs, and development activities) and stages of development (planning, budgeting, implementation, monitoring, evaluation), at each regional level. (district/city, province, national). The most important point of the process of developing Child-friendly districts/cities, namely the commitment of the regional head to realize the fulfillment of children's rights with the support of policy makers in the sub-districts and sub-districts, as well as coordination among stakeholders for the fulfillment of children's rights and policy makers carried out continuously and sustainably (Purba, 2017).

In line with the strategic plan of the government of the Republic of Indonesia relating to child prote ction as stated in Law Number 23 of 2002 as well as efforts to build the nation's generation in accordance with child development and also the Regulation of the Minister of Women's Empowerment and Child Protection of the Republic of Indonesia, Temusai Village was appointed as a child-friendly village. From the village first formed then sub-districtand district. If the village is not formed, the district will not be called a child-friendly city. Temusai village is the only village in Bungaraya that has been designated as a child-friendly village, because Temusai village has formed the managementand program of child-friendly village programs several months or years ago.

\section{a. The Child Friendly Village Program that has been carried out in Temusai Village, Bungaraya District, Siak Regency \\ 1) Community-Based Integrated Child Protection Campaign (PATBM)}

This campaign aims to provide understanding and awareness to the public about the importance of child protection by providing a child-friendly environment, so that children can grow and develop properly and provide understanding so that people pay attention to children's rights in everyday life and can increase awareness of children. both in the family and in the community, because children are the nation's potential for national development, so that their guidance and development needs to be carried out as early as possible by encouraging district, sub-district and village governments to formulate policies that favor the interests of children.

\section{2) Maghrib study program}

This program is expected to be able to bring children closer to religious values so that the provision of religious knowledge can make children not easily influenced by youth association and the influence of the globalization era which is increasingly open and it is hoped that children will be able to become a young generation who is polite and always applies religious values. in daily life.

3) Cooperate and coordinate with various parties in supporting the Child Friendly District Program (KRA)

In carrying out existing programs, support from various parties is needed, ranging from village officials, schools, the Temusai Village Children's Forum to Non-Governmental Organizations (NGOs) in Temusai Village as well as business actors or donor institutions who assist in the budgetand supports every activity and program that 
wants to be carried out and developed in order to create a child-friendly environmentand care about the rights of children in healthy growth and development.

\section{b. The Child Friendly Village Program in Temusai Village Chief's Decision No. 75/KPTS-TEM/2019 concerning the Establishment of the Temusai Village Children Friendly Task Force in 2019}

1. Fulfillment of the rights and protection of children in the sub-districtand in the village

2. Planning, developing, implementing and monitoring the Child Friendly District (KRA) development program

3. Services in the field of health and disease control

4. Services in the field of Primary and Secondary Education

5. Services in the field of security and order through Bhabinkamtibmas

6. Contribute to landscaping for children's playgrounds and recreation for children and families by involving the Business World or Donor Institutions

7. Empowering Non-Governmental Organizations for the Child Friendly Village Program (KLA)

8. Asking for help from the Temusai Village Children's Forum to socialize the Child Friendly Village (KRA) to their friends.

\section{Consult the needs and desires of children to partners from the relevant sector}

Based on the theory of legal protection, when it is associated with the function of law to provide protection. Protection is the provision of guarantees for security, tranquility, prosperity, and peace in the present, in the future and in the future. Likewise with the protection of children's rights, children have the right to obtain a more decent life and fulfill their rights and can grow and develop in a healthy and child -friendly environment and away from acts of violence and discrimination against children.

The essence of legal protection for children lies not only in the legal instruments, but other instruments such as society, environment, culture and guarantees for a bright future. So that it can be said that child protection efforts are creative efforts that make children able to live independently, namely children have the ability and willingness to use their rights and carry out their obligations as a child.

\subsection{Factors that become obstacles in implementing the child -friendly village program as an effort to prevent criminal acts of violence against children in Temusai Village, Bunga Raya District, Siak Regency \\ a. Lack of Professional Human Resources}

Article 22 of the Child Protection Law states that: "The State, Government, and Regional Governmentare obliged and responsible for providing supportfor facilities, infrastructure, and the availability of human resources in the implementation of Child Protection." The availability of human resources should be supported by a proportional and professional attitude. Proportional means that all treatment of children must pay attention to the limitations of the child's needs, age and condition, and professional is that human resources that provide protection to children are based on knowledge, skills, values, and ethics.

Understanding of child-friendly districts or villages must be given to all elements of society, including village officials so that there is one perception and one thought. In addition, it is also necessary for assistants and resource persons to provide counseling and socialization to the community, as well as psychologists in helping to restore psychological and psychosocial children when dealing with the law or who are victims and experience violence against children. The role of professionals is a supporting factor in carrying out the provision of protection and assistance to children who are victims of criminal acts (Komariah \& Noviawati, 2019).

\section{b. Limited technical guidance}

Village Temusai is the only village designated by the Bunga Raya Districtas a Child Friendly Village in 2019, so maximum guidance has not been given to all village officials regarding the activities carried out and how the implementation mechanism is. Although a Task Force has been formed in implementing the programs that have been determined, it has not been able to be implemented optimally, due to the lack of direction and gu idance from the local government, so that what is currently being done is only limited to what is known and what programs can 
be carried out to the community, meaning that existing and established programs have not been able to be implemented properly because of many obstacles in the field.

\section{c. Limited budget in carrying out existing programs}

Insufficientbudget is a big enough obstacle that must be faced by the Temusai Village/Kampungapparatus, so that it is not optimal in terms of providing assistance and counseling to the community, although there is cooperation with NGOs and Donor Institutions, it is still lacking and the Siak Regency local government should provide additional budgets in implementing Child Friendly Village programs so that the program can be implemented properly.

\section{d. Lack of supporting facilities and infrastructure for the Child Friendly Village Program}

Kampung Temusai needs supporting facilities and infrastructure in implementing the Child Friendly Village program, such as a child-friendly health center or hospital, a playground as a playground for children and families, child-friendly schools, professional teaching staff and understanding of education for children. and support the Child Friendly Village program. There are still many things that need to be addressed by Kampung Temusai, including instilling in the community the importance of protecting children and fulfilling children's rights in everyday life.

\section{e. Lack of public awareness in supporting the Child Friendly Village program}

The community must be given an understanding of the importance of providing a good environment for children, because a healthy, child-friendly environment will affect the growth and development of a child, a child who grows up in a good environment and fulfills children's rights properly will certainly become a strong and psychological person. healthy children, when compared to children who are far from being loved and protected for their rights, so socialization must be given to the community about the importance of providing a child -friendly environment, far from violence in realizing the best future for children.

This socialization is very important to be given and carried out so that the community knows the impact of violence on children, besides thatit also greatly affects the mental development of children in the future, so that the community must be given an understanding of the importance of taking measures to prevent violence against children, as well as training for task forces ( Task Force) which is given the task of providing assistance in the context of preventing violence against children.

The community must be given an understanding that violence against children is not an internal problem of a family so that it does not need to be known by others, but on the contrary, violence againstchildren is our shared responsibility including the government so that every occurrence of violence against children must be processed according to applicable law, including ifit is committed by other people. parents themselves, because children are the hope and future generations, if violence occurs, it will greatly affect the child's growth and developmentand the development of the child's personality, therefore it is our collective responsibility to always provide protection to children, if violence occurs immediately reported to the authorities and children must receive assistance and recovery from the violence they have experienced.

\subsection{Efforts made to overcome obstacles in implementing the Child Friendly Village Program}

\section{a. Coordinate with local governments regarding the budget that is still very minimal}

The very limited budget makes it difficult for the Village apparatus of Kampung Temusai to carry out the programs that have been determined, provide socialization and counseling to the community on the importance of paying attention to children's rights and providing protection for children. Kampung Temusai is the only village in Bunga Raya Subdistrict that is designated as a Child Friendly Village, it should also be supported with a clear and adequate budget to implement the Child Friendly Village program. The SiakRegency Government should provide its own budget to regulate and manage each of the programs that will be carried out so that the program can be carried out properly, because the mentoring and counseling are sustainable, notjust once but in stag es.

\section{b. Maximizing the role of social organizations both formal and non-formal in Temusai Village}

In the implementation of Child Friendly Village programs, collaboration with all parties is needed, including empowering all Community Organizations in Temusai Village and also maximizing the role of the Temusai Village Children's Forum, so that it is hoped that in the future it will be able to overcome all difficulties in the implementation of the Child Friendly Village, because basically protecting children and providing the bestlife for children by paying 
attention to children's rights in the growth and development of a child is our collective duty and responsibility not only the responsibility of a group of people but the responsibility of the community, nation and state because children are the hope of the nation who play a very importantrole in the development of the nation and state later.

\section{Conclusion}

Temusai village is the only village in Bungaraya that is designated as a child-friendly village. The Child Friendly Village Program that has been carried out in Temusai Village, Bungaraya District, Siak Regency is the Community-Based Integrated Child Protection Campaign (PATBM), the Maghrib Koran Program, Collaborating and coordinating with various parties in supporting the Child Friendly District Program (KRA), in addition to existing programs In the decision of the village head of Temusai regarding the Establishment of a Child Friendly Village Task Force, it still cannotbe implemented properly due to various obstacles in the field.

It is hoped that in the future the local government will pay more attention to the village or area and motivate or facilitate to develop into a child-friendly village and be able to supportlocal government programs, in addition to providing budget, supporting facilities and infrastructure so that the achievement of child-friendly villages can be carried out properly. In addition, in the future, Temusai Village should further enhance cooperation with various parties so that the process of becoming a child-friendly village is better and runs optimally by involving all elements of society and traditional stakeholders in Temusai Village.

\section{References}

Andini, T. M., Sulistyowati, T., \& Al., E. (2019). Identification of Violence againstChildren in Malang City. Journal of Women and Children (JPA), 2(1), 14.

H. Salim, H. (2010). Theory Developmentin Legal Studies. Jakarta: PT RajaGrafindo Persada.

Komariah, M., \& Noviawati, E. (2019). Model for handling child victims of sexual violence based on local wisdom in Pangandaran Regency. Galuh Justisi Scientific Journal, 7(2), 5.

Nuswantara, K., \& Savitri, E. D. (2018). Mengembangkan Kampung Literasi sebag ai Upaya Peningkatan Daya Berpikir Kreatif Imajinatif Anak-Anak Gang Dolly Melalui Penulisan Cerpen Layak Jual. SEWAGATI: Jurnal Pengabdian Kepada Masyarakat, 2(1).

Perdana, F. R. (2019). Pemberdayaan Berbasis Partisipasi Masyarakat Melalui Program Kampung Ramah Anak di Badran Kota Yogyakarta. Jurnal Pemberdayaan Masyarakat: Media Pemikiran Dan Dakwah Pembangunan, 3(1).

Purba, J. (2017). Law Enforcement Against Mild Crimes With Restorative Justice. Jakarta: Jala Permata Aksara.

Rusmiyati, C., \& Hikmawati, E. (2018). Implementasi Program Kampung Ramah Anak: dari Kampung Hitam Menuju LayakAnak. Jurnal Penelitian Kesejahteraan Sosial, 17(2).

Salam, S., \& Suhartono, R. M. (2020). The Existence Legal Certainty of the Truth and Reconciliation Commission in Indonesia. Musamus Law Review, 2(2), 76-85.

Wahid, A., \& Irfan, M. (2001). Protection of Victims of Sexual Violence (Advocacy for Women's Human Rights) (P. R. Aditama, ed.). Bandung.

Wijaya, A., \& Anantaa, W. peace. (2016). Sexual Crime Emergency. Jakarta: Sinar Graphic. 